\title{
ALBANIAN LANGUAGE AND DIALECT OF RAHOVEC
}

\author{
Fridrik Dulaj \\ University of Gjakova \\ Fridrik.dulaj@uni-gjk.org
}

\begin{abstract}
In this paper we will try to reflect the relationship of the standard language with the dialect of an area in Kosovo. In the city of Rahovec, in addition to the Albanian language, a language with a mixed lexicon is heard, Albanian, Serbian, Turkish, therefore the Albanian dialect is in circumstances of bilingualism and multilingualism. In these circumstances, during the historical development, Albanian and Serbian have interacted with each other. The relationship and relations of standard Albanian with dialectal forms will be treated in the framework of dialectal bilingualism. The object of review of the paper will be written documents and present discourse situations. To reflect the situation of Old Albanian in this dialect, we will refer to books written in this area, such as Divani of Sheh Maliqi or the Dictionary of Lubomir Kujonxhic. Meanwhile, the state of Albanian today will be reflected with examples collected in the field. Within the paper, we will compare the state and changes that have occurred in this dialect over time as a result of changes and historical circumstances, seeing them as sociolinguistic circumstances.
\end{abstract}

Keywords: language, bilingualism, dialectal bilingualism, lexicon, interaction, etc.

\section{Introduction}

\section{Develompent of Rahovec/ Rahovec dialect and its coexistence with the Albanian}

Before we go further it is important to see the possible origin of Rahovac/ Rahovec language. If we refer the history of Rrahovec/ Rahovecas an urban center, as a starting point we can consider residences that are found in the work of Selami Puhales where we mentioned before we have two sorts of Rahovec, great Rahovec/ Rahovec and small Rahovec. Both of them had 43 headed household (Pulaha, 1981, f.104). Its development and transformation in a small town ocured later. Recalling that only 500 families were in Rahovec/ Rahovec in 1892 (Nushiq, 1902, f.104-148). Albanians for the sake of developing their economy and comerce, perhaps to preverse their physical beign, started to communicate in the language of those who supplied Rahovec/ Rahovec with goods and who governed in the administrative sense. The need for business development pushed citizens of Rahovec/ Rahovec to subject the pressure of the language of those which whom they had intercourses. Albanian language was a native languagein Rahovec/ Rahovec clearly speak some old Albanian remants like the preservation of consonant groups: mb, nd, ng (Dulaj, 2016), ex. How is it going! (Puna e mbarë), Doing well! (Mbarë paq), Plant wheat! (mbjell grurë), Thanks, l exchange grapes with beans, don't mention, eating breead (hanger buk), 1 load wood (ngarkoj dru) etc.

Also, this idea can be reinforced through the Albanian's greeting words in the dialect of the town of Rahovec, except the usual greetings: good morning, good afternoon and good evening, good day and good night, and thank you, even though elders say (d'i Me J Hajra bofShajr). Even the dictionary of Lubomir Kujunxhiç, the words he wrote, show the bilingual situation in the city of Rahovec (Agani, 1981). Hilmi Agani emphasized "in the end of the nineteenth century and the beginning of 
this century) when the Kujunxhiqi's Dictionary was written in 1902, Albanian communication was in Albanian with Serbian language in addition when it came to business relation. In order to prevent the disappearance of Albanian language marriage with Albanian speakers only had an impact. But this didn't pass without consequences, disadvantage of Albanian language, citizens of Rahovec/ Rahovec started to use more dialect of Rahovec/ Rahovec in daily life replacing it with Albanian, even that Albanian was predominant for centuries (Agani, 1981).

For a predominant state of use of Albanian on Slavic and Rahovec/ Rahovec dialect Berni sllav Nushic (Nushiq, 1902) speaks in his book. But he said that Albanians once had spoken Serbian language and complains that they are abandoning language because of women that are coming from villages (Nushiq, 1902).

Relying in what Hilmi Agani says, in opinion of B. Nushnic also in language of Divan of Sheh Maliqit, that in Divan are used only five or six Slavic words we came to the conclusion that dialect of Rahovec/Rahovec has recognized two development stages. The first stage of maternity birth and use begins in 1912 when Kosovo was occupied by Serbia, a stage which will continue to develop until 1941 (Dulaj, 2016). With the beginning of World War II, the Slavic language began to exert pressure on the Albanian language in the city of Rahovec, but after the Second World War was over, the Serbian occupation was restored. During the first period according to the conducted surveys, citizens of Rahovec/ Rahovec were almost were subjected to the ruler, and as a consequence they damaged and misused their mother tongue, giving favors to artificial language, the Rahovec/ Rahovec dialect which has seemed to have taken on a culture character and civic identity on time to distinguish from the economically and unlettered backward peasantry (Dulaj, 2016). The destruction of Rahovec's national bed and the preservation of the Albanian language a lot of men fought in this locality.

Commitments of the citizens of Rahovec/ Rahovec in the National Movement were permanent and active. Well known heroes as Musa R. Rahoveci, Mustafa A. Derguti, Ali Sokoli to the last martyrs and soldiers of the KLA General who sacrificed their lives for their country along with other

martyrs in Kosovo. As stated above, it is clear that the Rahovec/ Rahovec folk tale in Rahovec/ Rahovec until the beginning of World War II had gone expanding into use and at the same time influencing, or interfering with, phonetics, morph syntax and the Albanian lexicon which had undoubtedly been active and considered as the native language of these residents. Sociolinguistic theory speaks of the interference of official languages on family language. Richard A. Hudson is the first who speaks about mixing codes and he emphasizes "the purpose of mixing codes, it looks like, symbolize an ambiguous situation, where using only one language is not enough" (Hudson, 2002).

Basil Shader in "Linguistic reviews between Albanian and German in Switzerland speaks also for "codswitching" and lists factors that affect in mixing of the language" "limited prestige of Albanians that live in Switzerland and the bilingual practice of Albanian Diaspora (Albanians that live in foreign country) influenced in damaging of Albanian language (Shaderi, 2005).

Further on, B. Shader lists three levels of "cod-switching" assessment that we have noticed in Rahovec's talk: a) Families that have always talked to families in dialect of Rahovec. In these families the mixture is at the high level or as a mixture of calls Shaderi B. "High Switch", b) families, that speak both dialect of Rahovec/ Rahovec and Albanian, have medium mix "Medium Switch", c) families that speak only in

Albanian have smaller mixture "Low Switch" 2 . Mixture of the language in those families may seem just as any phonetic phenomenon ex. Switching vibrating $r$ with $r$ field (arë) has gone to work in a field. According to this theory we can say that in the first part of the nineteenth century (Dulaj, 2016) Albanian language had limited prestige. Serbian language was used more because of occupation. Hilmi Maliqi in order to present the cruelty of Serbians over Albanians in Divan's nasheed (religious song) titled "A po ngo ni turk e vła" do you hear Turkish and brother, would write "erð kolera Serbija naj hot ha:kun Sejtnia" 
During the time we spent with my colleague from Rahovec/ Rahovec decoding and analyzing Divan's language of Sheh Maliqi from Rahovec, we need to find an expression within the verses of Divan, while we were in a silence and looking for in manuscript he was looking in Arabic alphabet and 1 in the manuscript (rewritten from a person that was born in Rahovec/ Rahovec in the beginning of last century) in Albanian alphabet my colleague cried out from joy "e gjeta- e dyta ilahia" (1 found second nasheed) in standard Albanian it should be "e Jeta Ilahia e dyta" ( 1 found the second nasheed). These influences did not have any affect in the phonetic and morph syntax system of the village folk of Rahovec. Slavic and dialect of Rahovec/ Rahovec did not affect the village speakers that even they borrowed some words they came as a result of administrative and business language ex. Opshtinë (municipality), naqallnik (senior police officer), pareznik (tax collector), upravnik (director). These words are used mainly by the elders because middle and young generation rarely use these words.

Today in the town of Rahovec/ Rahovec the middle and young generation still live-in bilingualism condition, Albanian and dialect of Rahovec (Dulaj, 2016). During the research we encountered different bilingual situations. Here is how the bilingual situation was expressed in a family in a neighborhood in Rahovec.

Grandmother didn't speak Albanian, her son graduated in University in 1990, got married to a girl whose family spoke only Albanian, they had two children and they were raised by their mother and she learnt them only Albanian and they spoke all the time in Albanian. Later they come to a situation where they can't communicate with their grandmother. We heard about this case in Rahovec/ Rahovec is a kind of "pact" not to talk in dialect of Rahovec.

Folësi: "A po liðim bes na se ma kur mos me fol ravecjânçen? Speaker: Will we promise not to talk in dialect of Rahovec/ Rahovec anymore?

“Turma prrjijet/ bravo profa/ tako je! (të lumtë profesor! Ashtu!). Crowd: Well, done professor

The state of bingualism in Rahovec/ Rahovec may be seen also as Albanian remnants in dialect of Rahovec.

Hilmi Agani in his study about linguistic region in Vocabulary of Lubomir Kujungjiqit talks about the impact that Albanian language had over Slavic language (Rahovec) (Nushiq, 1902), in our opinion this should be seen different. We agree with H.Agani that Albanian dialect of Rahovec/ Rahovec (Slavic as he calls it), like we have said before in phonetic and morph-syntax system, as a result of this interference Albanian language was damaged. So, if Albanian words in dialect of Rahovec/ Rahovec are considered influence we may flee from the truth that dialect of Rahovec/

Rahovec is built on the basis of languages like: Albanian, Slavic and oriental languages- Persian, Arabic and Turkish. That Albanian was influenced by dialect of Rahovec/ Rahovec in morph syntax structure prove some examples taken from this research.

Jimi ko:n te ni: msusi me msu germa// Ni: partiá e para neve jemi ko:n Jâft muj// (ne kemi qenë partia e pare gjashtë тиај).

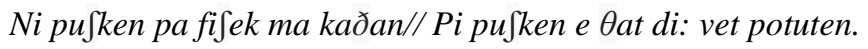

Po takoj kta hoxhen n'rug// Jemtfillun'Priftin tuj Sit ruS//Instead of acting forms we did.

Kusaret e kan hin me platskit ki:Sen//

(nuk përshtatet pjesorja e folje shynë me foljen ndihmëse kam . for example: kanë hi, për kanë hyrë apo janë hyrë ). (does not fit the part of the verb with the verb auxiliary I have for example: have hi, have entered or are entered). 
If this theory is acceptable, it appears that sociolinguistic factor affected morph-syntax and phonetic system, in dialect of Rahovec. Developing dialect of Rahovec, was not a good favor for Albanian language. The Albanian remnants within this "new language" for Albanians it's just preservation and not introduction of Albanian words. Hilmi Agani this sociolinguistic issue expressed by the phrase "language interference" and from this point of view, professor Agani should be seen as precursor of sociolinguistics in the development of linguistics in Kosovo.

Considering what we have said related to linguistic development we may conclude that social factors produce psycholinguistic effects. More we hear or search we are convinced that Albanian language is the first native language in Rahovec/Rahovec, without denying the fact that in any historic moment put Albanian in difficult situation, in this locality (Dulaj, 2016).

According to us Albanian language did not have any influence in dialect of Rahovec/ Rahovec and did not have the chance to influence but in a way, it served the language with necessary words. Those expressions that are heard as words, phrases, short lectures within the dialect of Rhovec are remnants of Albanian language which were not assimilated because of the interruption of development of dialect of Rahovec/ Rahovec which we think as we have said before there have been changes in world war 11 .

Phraseology and other linguistic elements that we face, convince us more that people of Rahovec/ Rahovec preserved and developed that spiritual creation in Albanian language. As evidence is the fact that citizens of Rahovec/ Rahovec don't know and don't want to sing in dialect of Rahovec, they always sin in Albanian, in weddings, national and religious festivals (nasheed, song of bekteshi's sect).

Here are some expressions that are common in dialect of Rahovec/ Rahovac with Albanian word in between (ti be šeshko e eja si Adem Peja (ti qenke shko e eja si Adem Peja)- You are as Adem Peja come and go, fatbardha nana zatebe (fatbardha nana përty)- your mum is lucky to have you, mu si zrgubelafija (i ka humb fija)-is confused, nikat ne vi daja ditt'bal (mos pafsh ditë të bardhë)-never have a good day, nemoj da binaš fjalët si Demushi, punt si kerkuši (mos u bë në fjalët si Demushi, punët si kërkushi)- don't speak like Demushi and business like no one, nema nićinvjet (nuk i ka njëqind vjet)-doesn't have hundred years, ne moj da çiniš hajgare (mos luaj hajgare)- don't play a joke, idemo Shkup e n'Shkoder- from Skopje to Shkoder, gaudarilimsiš (i karamsysh)- envy, "naniaqika" (qika e nënës)-mother's daughter.

Like we saw in those examples when the speaker finds difficult to find a proper word in that moment of speaking, they use words in dialect of Rahovec/ Rahovec.

\section{Spoken language and art language}

For a long time, we have heard a story that it was an analog for arbreshet(italo-albanians). Our interlocutor trying to show us his feelings and world among the others he said "Kurpoflej un poshohiandre:nshqip, edhekurpomendojpomendojshqip. E kurpofolipoperzi her shqip her gjuhenravecjançe" when 1 sleep 1 dream in Albanian even when 1 think 1 think in Albanian, but when 1 speak 1 mix Albanian with dialect of Orahovac.

This proves that citizens of Rahovec/ Rahove care emotionally connected to Albanian language. It looks like the social factor influenced first phonetic of Albanian speakers of Rahovec, then grammatical system, but couldn't affect their linguistic psychology. When we asked how the conversation was developed in his dreams he responded.

Ná n'ânder kur po lujm nuk po folim rahovetsiantfel ati: (aty) po folim

†isto Sqip// Un (vazhdon subjekti) e kam zјeð pikturen si profesion nə mungesa tə mundasias sa

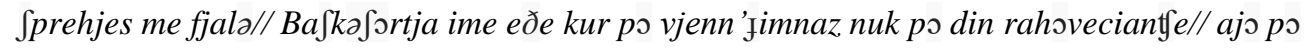
mson rahovetsiantfen kur povjen n'Jkoll / n'xhimnaz // 
(in my dreams we don't speak or play in dialect of Rahovec/ Rahovec but in Albanian, 1 choose picture as a profession in order to express myself when 1 can' through words. When my wife comes to high school, she don't speak in dialect se she is learning dialect there).

Here are some examples proving that psychological effects interfere in spoken language. A citizen of Rahovec/ Rahovec goes to his uncle in another village to express condolences and he addresses to the head of household:

Rahoveciani : o Isa: a ka dék dajá Januz á?

Katundari: $P$ o ,ia- kөeu pritəsi.

The citizen trying to find a proper word to express condolence he says it's good that he is dead. Another case:

Rahoveciani: o dajá Imer a kade:k Xhema á?

Imeri: $P$ ऽ / daj//

Rahoveciani-Bogatte da bereqet. (zoti të dhashët bereqet). An expression that is used mainly when a pet dies. Those expressions are unstoppable and it can't be said when those Slavic expressions and foreign unnecessary words won't be used anymore. A beautiful story taken from the book "War Memories" that speaks for Jashari family during the war, the word driver "driver" was spotted.

-Come in, because we are leaving- the bus driver called us.

-A country girl whose boyfriend Rahovec/ Rahovec often spoke in dialect of Rhovec as a joke she would say: pite par pyte (question), a je ka ๖oh/ ktiri punt e veta ti par Jih punat tua (mind your own business), menjamalle, zezakres(edhe kris per mendja madhe, e zezakresë, ( being conceit damaging yourself). It happens to hear also phrases like: ku:r po bahet neseral par to nesərmen (tomorrow),

A un jam faj ci's po di $a$ ? (is it my fault that you don't know) Mbite gojen, mbiłe vratal/ (shut up).

Meanwhile a construction engineer would use words as water circulation system, a mechanic who worked in Germany testing the car would say nukkatyf per nukka test (I don't have a test). During the period of 1980 H.Dulaj stayed in Kalabri to study some issues, during the visits he has done in accompaniment of a priest he testifies: In Fakullnar ( municipality of Italy) he visited two families in a first family when the father and son both of them married to Italian women, they and their children spoke in Albanian but none of their wives did, the second situation is about an arbreshe mother and Italian father they had twin girls, twins and woman spoke in Arbreshe but the father didin't. In University of Kalabria he met over thirty students which came from different parts of Italy and all of them spoke in "arbreshe" except one who started to learn arbreshe dialect was influenced by other students. He was called Besnik.

\section{Conclusion}

What keeps alive dialect of Rahovec/ Rahovec in Rahovec/ Rahovec city remains to be seen in the future. If you say to a citizen of Rahovec that you are speaking Serbian when he is speaking in dialect, he won't feel good. Because they consider their language different from Serbian. It happened to a citizen of Rahovec/Rahovec when he went to Belgrade but he wasn't able to communicate with Serbian because he spoke in his own language. He didn't speak Serbian neither. Serbian didn't speak his language. Another fact that happened during the war is while they were going in a battle during the action, they spoke in dialect other soldiers though that they were camouflaged in UQK's uniform and almost shouted them. 
ISSN 2661-2666 (Online) International Scientific Journal Monte (ISJM) DOI: 10.33807/monte.20211844

Volume 4, (No).1 (2021): April

\section{References}

Agani, H. (1981). Fjalori i Lubomir Kujunxhiçit. Rilindja. Prishtinë

Dulaj, F. (2016). E folmja e Rahovecit me rrethinë. IAP.

Nushiq, Branisllav. (1902). S’Kosova nasnje more.

Pulaha, S. (1981). Popullsia shqiptare e Kosovës gjatë shekujve XV-XVI. ADHSH.

Shaderi, B.(2006). Shqyrtime gjuhësore rreth kontaktit mes shqipes dhe gjermanishtes në Zvicër, Kristalina-KH. 